Reprod. Nutr. Dévelop., 1985, 25 (5), 993-1005.

\title{
Control of aldosterone secretion in domestic mammals during the perinatal period
}

\author{
J. GIRY, A. SAFWATE, J.-P. BARLET $(*)$
}

Laboratoire de Physiologie Animale et U.A. C.N.R.S. 041123

Université de Clermont-Ferrand II, B.P. 45, 63170 Aubière, France.

(*) I.N.R.A. Theix, 63122 Ceyrat, France.

Summary. Aldosterone in ovine fetal circulation is mainly of fetal origin. Three of the renin-angiotensin system (RAS) parameters (renin, renin substrate and angiotensin II) originate in the fetus. The fetal RAS responds to stimulation (furosemide administration, hemorrhage, hypoxemia) or inhibition (phenylephrine or agiotensin II infusion) in a manner similar to that of the adult. The response of the fetal adrenal gland to angiotensin II is agedependent and the near-term adrenal gland is not fully sensitive to angiotensin II and relatively insensitive to potassium $\left(\mathrm{K}^{+}\right)$as well as to adrenocorticotrophin hormone (ACTH) stimuli. In the newborn, the RAS is fully operative since it responds to diuretic stimulation in the lamb and the calf or to inhibition by angiotensin II administration in the lamb. Angiotensin II infusion, or angiotensin-converting enzyme blockade in the newborn lamb is followed by changes in plasma renin activity (PRA) or plasma aldosterone concentration (PAC) that suggest that angiotensin II regulates aldosterone secretion and that there is a negative feed back loop between angiotensin II and renin release. The newborn lamb adrenal gland is sensitive to potassium ions while in the newborn calf, ACTH stimulates cortisol secretion but fails to induce any change in PAC, suggesting that, in this species, the zona glomerulosa of the adrenal cortex is insensitive to ACTH.

\section{Introduction.}

Aldosterone is the salt-retaining steroid of the adrenal cortex. It regulates sodium balance by acting directly on the distal tubule of the nephron to stimulate sodium conservation and thus contributes to the maintenance of extra-cellular fluid volume.

The renin-angiotensin system increases aldosterone production by the adrenal cortex and is one of the factors controlling blood pressure; it acts on the vasculature through angiotensin II, the most active, natural vasoconstrictor known. At birth, the newborn animal is faced with a dry environment in which the conservation of sodium and water are of primary importance. At the same time hemodynamic changes occur such as the onset of pulmonary circulation and occlusion of the umbilical-placental circulation. It is thus of interest to determine

Reproduction, Nutrition, Développement $n^{\circ}$ 5-1985, -11 
the mechanisms regulating aldosterone secretion during fetal life and immediately after birth.

In our laboratory, aldosterone secretion during the perinatal period has been studied in three species of domestic mammals : ovines, bovines and equines. The present review has been limited to these species.

1. Changes in plasma aldosterone concentration (PAC) during the perinatal period.

As seen from figure 1 , aldosterone is present in the fetal circulation of ovines and bovines; immediately after birth, the plasma aldosterone level in lambs, calves and foals is higher than at the end of the first neonatal week; changes in $\mathrm{PAC}$ in these three species are similar and are marked by a progressive decrease after birth.

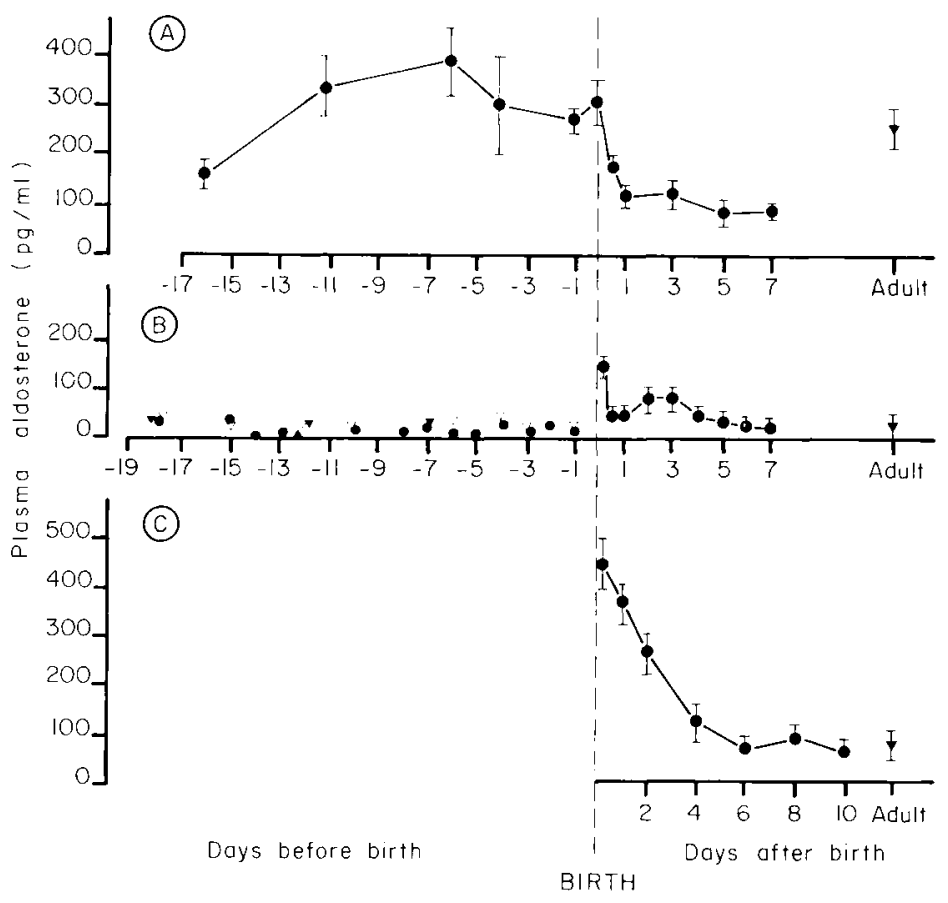

FIG. 1. - Plasma aldosterone concentration during the perinatal period in three species of domestic mammals.

A (ovine ; Moncaup et al., 1980 ; Sawate et al., 1984)

B (bovine ; Safwate et al., 1982a ; Rouffet et al., 1984)

C (equine ; Giry et al., 1979)

\section{Regulation of aldosterone secretion in the fetus.}

The control of aldosterone secretion in adults depends on three major stimuli : the renin-angiotensin system (RAS), potassium ions $\left(K^{+}\right)$and adreno- 
corticotrophin hormone (ACTH). Since direct control of aldosterone secretion during fetal life has been studied only in sheep and no information on this subject is available in cattle or horses, this section of the review will only discuss data obtained in sheep.

2.1. Origin of aldosterone in fetal circulation. - Before studying the control of aldosterone secretion in the ovine fetus, it is imperative to know whether the fetal adrenal gland can synthesize and secrete aldosterone and also whether the hormone present in the fetal plasma (table 1) is of fetal origin.

\section{TABLE 1}

Plasma aldosterone concentration in the ovine fetus and the pregnant ewe bearing chronic vascular cannulae (mean \pm SEM).

\begin{tabular}{|c|c|c|c|c|}
\hline \multirow{2}{*}{\multicolumn{2}{|c|}{$\begin{array}{c}\text { Stage } \\
\text { (Days of gestation) }\end{array}$}} & \multicolumn{2}{|c|}{$\begin{array}{l}\text { Aldosterone } \\
\mathrm{pg} / \mathrm{ml}\end{array}$} & \multirow{2}{*}{ Reference } \\
\hline & & Fetus & Pregnant ewe & \\
\hline Term : & $\begin{array}{l}142-152 \\
100-109 \\
110-140 \\
140-\text { Term }\end{array}$ & $\begin{array}{r}* 87 \pm 25 \\
* 44 \pm 12 \\
* 115 \pm 20\end{array}$ & $* 12 \pm 4$ & Brown et al. (1978) \\
\hline Term : & $\begin{array}{r}147 \\
120-130\end{array}$ & $79.9 \pm 50.4$ & $87.9 \pm 9.5$ & Broughton-Pipkin and $O^{\prime} B$ rien (1978) \\
\hline Term : & $\begin{array}{l}145 \pm 1 \\
130 \\
140 \\
145\end{array}$ & $\begin{array}{r}171 \pm 10 \\
384 \pm 59 \\
248 \pm 13 \\
\end{array}$ & $\begin{array}{l}775 \pm 55 \\
164 \pm 7 \\
228 \pm 23 \\
\end{array}$ & Moncaup et al. (1980) \\
\hline Term : & $\begin{array}{l}140-150 \\
120 \\
125\end{array}$ & $\begin{array}{l}34.5 \pm 5.3 \\
66.7 \pm 12.1\end{array}$ & $\begin{array}{c}58.3 \pm 7.6 \\
122.8 \pm 28.7\end{array}$ & Siegel (1981a) \\
\hline Term: & $\begin{array}{r}145 \\
120 \\
130\end{array}$ & $\begin{array}{l}41 \pm 5 \\
47 \pm 9\end{array}$ & & Robillard et al. (1982a) \\
\hline
\end{tabular}

*Blood aldosterone concentration

In vitro studies have shown that the ovine fetal adrenal gland can synthesize and secrete aldosterone very early in gestation (Wintour et al., 1975). In the same species, direct adrenal vein cannulation showed aldosterone to be a secretory product of the fetal adrenal gland (Alexander et al., 1968 ; Wintour et al., 1975). Studies in pregnant ewes and chronically catheterized fetal lambs, in which labelled aldosterone was infused alternately into the maternal and fetal compartments, demonstrate that aldosterone in the fetal circulation originates mainly from the fetal adrenal gland. Using such a long-term lamb preparation, Moncaup et al, (1980) failed to detect any transplacental passage of the hormone, while Wintour et al., (1980) showed that the mother contributed less than $20 \%$ to fetal aldosterone concentration. 
It should be noted that when $d$-aldosterone monoacetate was infused into the fetus, leading to a 20 -fold increase in fetal PAC, Siegel et al., (1981a) also observed a 2-fold increase in maternal plasma levels, suggesting that aldosterone could cross the placenta during the last trimester of gestation. The very high levels of d-aldosterone monoacetate infused $(100 \mu \mathrm{g} / \mathrm{kg} \mathrm{IV}$ bolus and $100 \mu \mathrm{g} / \mathrm{kg}$ over $60 \mathrm{~min}$ ) could have annulled the ability of the liver and/or of the placenta to metabolize aldosterone. Moncaup et al. (1980) detected labelled tetrahydroaldosterone in the fetal circulation when the ewe was infused with labelled aldosterone and the same metabolite in maternal blood when the fetus was infused with the radioactive hormone.

2.2 The RAS in fetal lambs (table 2). - Granulated juxtaglomerular cells have been found in the kidney of fetal lambs (Smith et al., 1974) but it is not reported whether the fetal kidney is able to release renin into the fetal circulation. Plasma renin concentration (PRC) or plasma renin activity (PRA) would be better evidence of fetal kidney secretion if there were no transplacental passage of renin from the ewe to the fetus.

Data from two ewes, in which PRC was determined in one fetus after nephrectomy, revealed that it was detectable but considerably lower than that of the non-nephrectomized fetus (Broughton-Pipkin et al., 1974b); these data were confirmed by the effect of bilateral fetal and maternal nephrectomy on basal (Moutquin and Liggins, 1976), diuretic-stimulated (Oakes et al., 1977) or hemorrhage-stimulated (Robillard et al., 1982a) PRA.

In chronically cannulated binephrectomized fetuses there were no significant changes in PRA and plasma angiotensin II concentration during furosemide injection or hemorrhage. Furosemide administration to the mother was followed by a prompt increase in maternal PRA without any change in fetal levels. Thus, fetal PRA is independent of maternal PRA in pregnancy, and renin cannot cross the ovine placenta.

Similar results regarding renin substrate have been reported by Carver and Mott (1978). As indirect evidence tends to indicate that angiotensin II does not cross the ovine placenta (Iwamoto and Rudolph, 1981; Robillard et al., 1982a), it seems reasonable to conclude that three of the RAS parameters (renin, renin substrate and angiotensin II) originate in the fetus.

\subsubsection{Fetal RAS response to stimulation.}

- Administration of furosemide, a potent natriuretic agent. - In the acute $f$ lamb preparation, furosemide administration was followed by a significant ris. PRC (Trimper and Lumbers, 1972). This could have been due to stressful conditions (anaesthetization and exteriorization of the fetus) which is why Fleischman et al. (1975) studied the effect of furosemide injection and Siegel and Fisher (1980) the effect of furosemide infusion in chronically cannulated animals. Fleischman et al. (1975) found this response depended on the basal levels of PRA, while Siegel and Fisher (1980) found it to be age-dependent since 


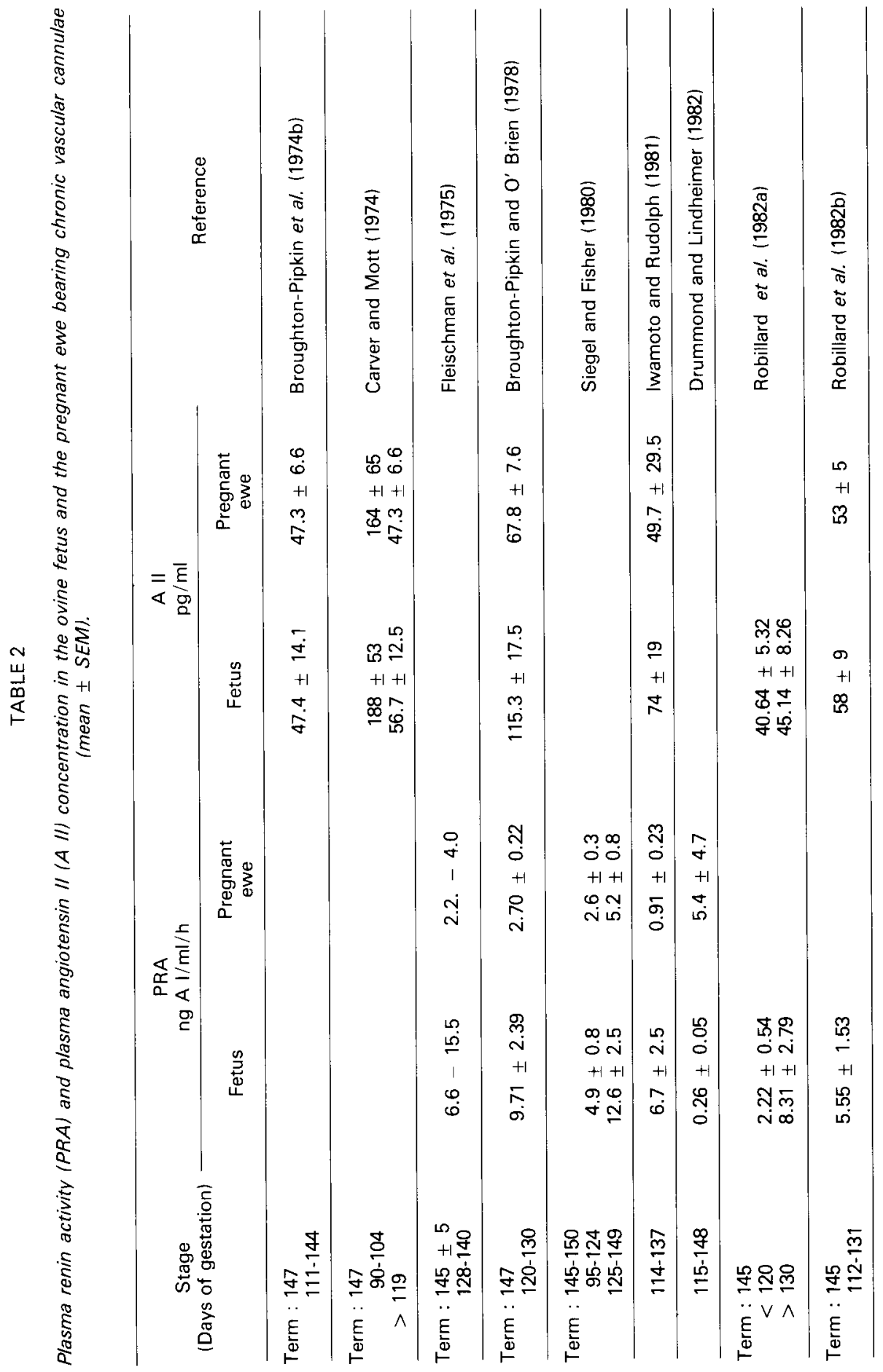


furosemide failed to alter basal PRA levels in fetuses at less than 106 days of gestation but stimulated fetal renin secretion in near-term fetuses.

- Fetal RAS response to hemorrhage. - Removal of blood from the fetal circulation either in the acute maternal-fetal preparation (Broughton-Pipkin et al., 1974a ; Smith et al., 1974) or in chronically instrumented fetal lambs (BroughtonPipkin et al., 1974b ; Mattioli et al., 1979 ; Iwamoto and Rudolph, 1981 ; Robillard et al., 1982a) was accompanied by a prompt rise in PRC, PRA and angiotensin II concentrations.

Robillard et al. (1982a) studied three different hemorrhage levels in fetal lambs at less than 120 days and over 120 days of gestation. They observed a significant elevation of the PRA level and plasma angiotensin II concentration, depending on fetal age since the increase in both parameters was more pronounced in near-term fetuses than in those under 120 days of gestation.

- Fetal RAS response to hypoxemia. - Fetal hypoxemia induced either by restricting maternal access to $\mathrm{O}_{2}$ (Drummond and Lindheimer, 1982 ; Robillard et al., 1984) or by reducing uterine blood flow (Moutquin and Liggins, 1981) enhanced PRC and PRA levels as well as plasma angiotensin II concentration.

- Fetal RAS response to other stimuli. - Fetal hypotension caused by the intravenous infusion of sodium nitroprusside or $\beta$-adrenergic stimulation (isoprenaline) was associated with an increase in fetal PRA (Lumbers and Lewes, 1979). However, it should be noted that exogenous adrenaline did not induce any change in PRC (Broughton-Pipkin et al., 1974b) or PRA (Lumbers and Lewes, 1979).

\subsubsection{Fetal RAS response to inhibition}

In the near-term chronically instrumented fetal lamb, a rise in fetal arterial blood pressure after infusion of either phenylephrine (Lumbers and Lewes, 1979) or angiotensin II (Siegel et al., 1981b ; Robillard et al., 1982b), was followed by a significant decrease in fetal PRA, suggesting that angiotensin II has a direct negative feedback effect on renin release from the juxtaglomerular cells of the fetal kidney. It should be remembered however that fetal hypertension could be associated with an increase in fetal renal perfusion pressure which is known to suppress renal renin secretion.

\subsubsection{Fetal plasma aldosterone response to RAS}

As seen previously, the RAS in fetal lambs is stimulated either by administration of a diuretic (furosemide) or by reduction of blood volume (hemorrhage). When concomitant plasma aldosterone measurements are compared, the results are conflicting. Siegel and Fisher (1980) did not observe any change in plasma aldosterone levels in lambs at either 95-106 or 123-142 days of gestation after furosemide infusion, while Robillard et al., (1982a) observed a significant increase in plasma aldosterone concentration during hemorrhage in fetuses over 130 days of gestation. The rise in PAC correlated closey with the rise in plasma angiotensin 
II concentration, suggesting that the fetal adrenal gland has the ability to secrete aldosterone in response to angiotensin II. The question of maturing fetal gland sensitivity arises because there is no significant change in baseline aldosterone level during hemorrhage in fetuses under 120 days of gestation, despite a significant increase in plasma angiotensin II concentration. Angiotension II infusion into the fetal circulation causes an increase in PAC (Siegel et al., 1981b; Robillard et al., 1982b) but when similar plasma angiotensin II concentrations are achieved by angiotensin II infusion into fetal lambs or adult non-pregnant ewes, significantly higher plasma aldosterone levels are found in the adults than in the fetuses (Robillard et al., 1982b). These results suggest that the response of the fetal adrenal gland to angiotensin II is age-dependent and that the near-term fetal adrenal gland is not fully sensitive to angiotensin II.

2.3. Potassium ions $\left(K^{+}\right)$and fetal aldosterone secretion. - In in vitro studies Wintour et al. (1975) demonstrated the ability of the ovine fetal adrenal cortex to increase its aldosterone prodution in response to a rise in $\mathrm{K}^{+}$concentration after 120 days of gestation.

In chronically instrumented fetal lambs, Dutton and Mott (1980) and Robillard et al. (1982a) found a close correlation between plasma aldosterone and plasma $\mathrm{K}^{+}$levels in binephrectomized fetuses, with or without hemorrhage, indicating that under certain conditions, changes in $K^{+}$levels may influence aldosterone secretion during fetal life.

$\mathrm{KCl}$ infusion into chronically cannulated fetuses (109-145 days of gestation), in order to increase fetal plasma $K^{+}$levels from 0.3 to $1.5 \mathrm{mmole} / \mathrm{l}$, failed to induce any change in PAC (Wintour et al., 1979). Similarly, in captopril and dexamethasone-treated fetal lambs (131-143 days of gestation) hypoxemia was associated with a significant increase in $\mathrm{K}^{+}$concentration without any change in PAC (Robillard et al., 1984). These results suggest that the fetal adrenal gland is relatively insensitive to the $\mathrm{K}^{+}$stimuli which are within its physiological range.

2.4. ACTH and fetal aldosterone secretion. - When the ovine fetal adrenal gland is incubated with ACTH, this peptide is a potent stimulus to aldosterone production in 60 to 90 -day old fetuses, but its effect declines in 91 to 120-day old fetuses (Wintour et al., 1975). ACTH infusion in acute fetal-maternal sheep preparation (Alexander et al., 1968) or in fetal lambs with indwelling catheters (Brown et al., 1978) fails to increase aldosterone in adrenal venous blood or in systemic blood during the last trimester of gestation, even though a rise in cortisol concentration attests to fetal gland stimulation.

More recently, Pradier et al. (1985) demonstrated that the injection of ovine corticotropin-releasing factor into chronically cannulated fetal lambs $(120,130$ and 137 days of gestation) is accompanied by an increase in ACTH and plasma cortisol concentration without any effect on PAC. These data suggest that the fetal adrenal gland in vivo is relatively insensitive to ACTH. It should be pointed out however that under stressful conditions such as hypoxemia, which is known to induce ACTH release (Boddy et al., 1974), this peptide may modulate 
aldosterone secretion since, in the presence of a converting enzyme blockade (captopril), plasma aldosterone levels are lowered by dexamethasone administration (Robillard et al., 1984). Whether ACTH can stimulate aldosterone secretion in the pre-term ovine fetus is still open to debate.

\section{Regulation of aldosterone secretion in the newborn}

3.1. At birth. - As seen in figure 1, plasma aldosterone levels are high in lambs and calves immediately after birth. It is tempting to speculate on the possibility that, since stressful parturition is accompanied by a rise in plasma ACTH in both lambs (Jones et al., 1977) and calves (Richet et al., 1984), the adrenal gland of the newborn responds to ACTH stimulation.

Twelve hours after birth, Safwate et al. (1984) did not observe any difference in PAC either in vaginally-born lambs or in those delivered by cesarean section. Unfortunately, they did not measure PAC immediately after birth. As the activity of the RAS has not been assessed yet by PRA or angiotensin II measurement in lambs or calves, the mechanisms responsible for the high PAC at birth need further investigation. Changes in hepatic metabolism might also be involved since the birth of lambs is associated with a marked fall in aldosterone metabolic clearance rate (Moncaup et al., 1980).

\subsection{In the newborn during the postnatal period.}

3.2.1. The RAS and aldosterone secretion.

In control newborns (table 3). - The plasma renin levels in term newborn lambs are consistently elevated above adult values during the postnatal period (Fleischman et al., 1975; Siegel and Fisher, 1980; Robillard et al., 1980).

\section{TABLE 3}

Plasma renin activity (PRA) and plasma aldosterone concentration in the newborn (mean $\pm S E M$ ).

\begin{tabular}{|c|c|c|c|c|}
\hline Stage & $\begin{array}{c}\text { PRA } \\
\mathrm{ng} A \mathrm{l} / \mathrm{ml} / \mathrm{h}\end{array}$ & $\begin{array}{c}\text { Aldosterone } \\
\mathrm{pg} / \mathrm{ml}\end{array}$ & Species & Reference \\
\hline $\begin{array}{l}\text { Less than } \\
\text { one week }\end{array}$ & $\begin{array}{l}21.5 \pm 2 \\
{ }^{*} 4.2 \pm 0.78\end{array}$ & $\begin{array}{l}118 \pm 20 \\
* 55 \pm 11\end{array}$ & Ovine & Siegel and Fisher (1980) \\
\hline $2-3$ weeks & $\begin{array}{l}24.5 \pm 2.3 \\
{ }^{*} 1.7 \pm 0.7\end{array}$ & $\begin{array}{l}174 \pm 50 \\
{ }^{*} 43 \pm 7\end{array}$ & Ovine & Siegel (1981b) \\
\hline $3-8$ days & $\begin{array}{l}17.6 \pm 3.9 \\
* 1.28 \pm 0.34\end{array}$ & $\begin{array}{l}46.5 \pm 7.09 \\
{ }^{*} 63 \pm 17\end{array}$ & Ovine & Robillard et al. $(1980,1982 b)$ \\
\hline 3 days & $\begin{array}{r}3.1 \pm 1.1 \\
* * 1.2 \pm 0.4\end{array}$ & $\begin{array}{c}47 \pm 18 \\
* * 26.7 \pm 4.9\end{array}$ & Bovine & Safwate (1985) \\
\hline
\end{tabular}

*Non-pregnant adult ewe

**11-month-old-bull 
Similarly, plasma aldosterone levels are higher than those of adults (Siegel and Fisher, 1980) and are closely related to PRA in lambs less than one week old (Robillard et al., 1980) ; this suggests RAS activation during the postnatal period. These observations have not been confirmed in 3-day old calves since PRA levels are only slightly higher than those of adults, while PAC levels are similar to those of adults (Safwate et al., 1982a ; Safwate, 1985). It should be noted that Safwate et al. (1982a) showed sodium balance in calves to be positive in day-to-day measurements over the first postnatal week, while the study by Siegel and Fisher (1980) in lambs was not carried out under conditions of controlled sodium intake. In natriuretic-treated newborns. - Intravenous injection (Fleischman et al., 1975) or infusion (Siegel and Fisher, 1977, 1980) of furosemide in lambs or injection of a mixture of ethacrynic acid and hydrochlorothiazide (EAH) in 3-day old calves (Safwate, 1985) was accompanied by a rise in both PRA and PAC.

The acute (1-2 $\mathrm{min})$ infusion of furosemide to lambs did not induce any change in plasma sodium concentration or blood hematocrit, while 6-hour EAH infusion in calves was associated with a decrease in plasma sodium concentration and hematocrit. The hormonal changes observed in newborns of both species were similar however and were marked by a prompt increase in PRA levels and delayed aldosterone response.

PRA levels are low in anephric lambs (Siegel and Fisher, 1979), indicating that the kidney is the major source of renin. As furosemide is known to enhance the amount of $\mathrm{Na}^{+}$delivered to the macula densa receptor and thus to elicit renin release by the renal juxtaglomerular cells in the adult, it is possible that a similar mechanism operates in the newborn lamb. The results of Siegel and Fisher (1980) support this conclusion since they did not observe any change in plasma sodium concentration or blood volume in furosemide-infused newborn lambs.

- In angiotensin //-infused or captopril-treated newborns. - Continuous infusion of angiotensin II in newborn lambs was followed by a decrease of PRA and an increase of PAC, suggesting that the newborn adrenal gland is sensitive to angiotensin II and that there is a negative feedback loop between angiotensin II and renin release (Siegel, 1981b). Inhibition of the angiotensin-converting enzyme with captopril in chronically catheterized 2 to 38-day old lambs was associated with a decrease in plasma angiotensin $I I$ and aldosterone concentrations (Weismann et al., 1983), indicating that in the newborn lamb angiotensin II regulates aldosterone secretion.

In a longitudinal study in maturing newborn lambs, Wilson et al. (1981) observed that angiotensin suppression of PRA did not change as the lambs matured, while the aldosterone response was diminished in immature lambs less than 8 days old compared to the aldosterone response in the same lambs when older. Thus, the adrenal gland of the newborn lamb can respond to angiotensin II stimulation but might not be fully sensitive to this peptide.

3.2.2. Changes in $K^{+}$concentration and aldosterone secretion. - Nephrectomy in the newborn lamb is followed by a rise in plasma $K^{+}$levels and PAC (Siegel and Fisher, 1979). The infusion of $\mathrm{KCl}$ elicits an increase in both plasma $\mathrm{K}^{+}$and aldosterone concentrations without any change in PRA and sodium 
concentrations or the hematocrit. These results indicate that potassium ions might regulate aldosterone secretion in the newborn lamb (Siegel, 1979).

3.2.3. ACTH and aldosterone secretion. - ACTH infused into 11-day old calves stimulates cortisol secretion, as shown by a prompt increase in plasma cortisol levels, but it fails to induce any change in PAC (Safwate et al., 1982b). More recently, similar results were obtained in 3-day old calves (Safwate, unpublished data), suggesting that the zona glomerulosa of the newborn calf adrenal cortex is insensitive to ACTH.

\section{Conclusions}

In the fetal lamb during the last trimester of gestation, plasma aldosterone originates mainly from the fetal adrenal gland. The RAS is fully operative and responds to stimulation or suppression in a manner similar to that of the adult. Under basal conditions, the fetal adrenal gland is not sensitive to ACTH or $\mathrm{K}^{+}$ ions and responds only to RAS stimulation. Adrenal gland response depends on the age of the fetus since angiotensin II stimulation becomes more effective in causing aldosterone release as the fetus nears term.

In the newborn lamb and calf, the RAS is functional and responds to stimulation. Renin release by the newborn kidney can be suppressed by angiotensin II in the lamb, and the negative feedback inhibition of angiotensin II on renin release is similar throughout the first month of postnatal life while aldosterone response to angiotensin II is age-dependent.

In the lamb, potassium ions modulate aldosterone secretion by the adrenal gland, while in the calf the adrenal zona glomerulosa is insensitive to ACTH.

In both the fetus and the newborn, the RAS appears to play a major role in the control of aldosterone secretion. Although aldosterone can alter the excretion of sodium and potassium in the urine (Lingwood et al., 1978 ; Robillard et al., 1980 ; Siegel et al., 1981a ; Safwate, 1985), its role in sodium homeostasis is not clear in either the fetus or the newborn.

Réunion d'Endocrinologie de l'Association des Physiologistes, Clermont, 23-24 Avril 1985.

Résumé. La régulation de la sécrétion d'aldostérone au cours de la période périnatale chez les mammifères domestiques.

Chez le fœtus ovin, l'aldostérone, détectée dans la circulation fœtale, provient essentiellement des surrénales du fœetus. Trois des composantes du système rénine-angiotensine (SRA), la rénine, l'angiotensinogène et l'angiotensine II sont d'origine fœtale. Le SRA fœtal répond aux tests de stimulation (administration de furosemide, hémorragie) ainsi qu'aux tests de freination (administration de phénylephrine ou d'angiotensine II) d'une manière semblable à celle de l'animal adulte. Cependant, bien que la surrénale fœetale libère de 
I'aldostérone sous l'action de l'angiotensine II, l'intensité de la réponse est d'autant plus élevée que le terme se rapproche, sans toutefois atteindre celle de l'animal adulte, ce qui permet de suggérer une moindre sensibilité de la surrénale fœtale ovine à l'angiotensine II. De même, la surrénale du fœtus ovin est relativement insensible à l'action des ions potassium $\left(\mathrm{K}^{+}\right)$ou de l'hormone corticotrope (ACTH). Chez le nouveau-né, le SRA est fonctionnel et répond à la stimulation consécutive à l'administration d'un diurétique chez l'agneau et le veau ainsi qu'à la freination suite à la perfusion d'angiotensine II chez l'agneau. Les modifications de l'activité rénine plasmatique (ARP) et des concentrations plasmatiques en aldostérone que l'on observe après administration d'angiotensine II ou inhibition de l'enzyme de conversion chez l'agneau nouveau-né permettent de conclure que l'angiotensine II contrôle la sécrétion d'aldostérone et qu'il existe un rétro-contrôle négatif entre l'angiotensine II et la libération de rénine au cours de la période postnatale dans cette espèce. La surrénale de l'agneau nouveau-né est sensible aux ions potassium alors que chez le veau, si l'administration d'ACTH stimule la libération de cortisol, elle n'entraîne aucune modification de la sécrétion d'aldostérone. II semble donc que la zone glomérulée du cortex surrénal est relativement insensible à ACTH au cours de la période postnatale dans cette espèce.

\section{References}

ALEXANDER D.P., BRITTON H. G., JAMES V. H. T., NIXON D. A., PARKER R. A., WINTOUR E. M., WRIGHT R. D., 1968. Steroid secretion by the adrenal gland of foetal and neonatal sheep. J. Endocr., 40, 1-13.

BODDY K., JONES C. T., MANTELL C., RATCLIFFE J. G., ROBINSON J. S., 1974. Changes in plasma ACTH and corticosteroid of the maternal and fetal sheep during hypoxia. Endocrinology, 94, 588-591.

BROUGHTON-PIPKIN F., KIRKPATRICK S. M. L., LUMBERS E. R., MOTT J. C., 1974a. Renin and angiotensin-like levels in foetal, newborn and adult sheep. J. Physiol. (London), 241, 575-588.

BROUGHTON-PIPKIN F., LUMBERS E. R., MOTT J. C., 1974b. Factors influencing plasma renin and angiotensin $I I$ in the conscious pregnant ewe and its foetus J. Physiol. (London), 243. 619-636.

BROUGHTON-PIPKIN F., O'BRIEN P. M. S., 1978. Effect of the specific angiotensin antagonist $\left(\mathrm{Sar}^{1}\right)\left(\mathrm{Ala}{ }^{8}\right)$ angiotensin II on blood pressure and the renin angiotensin system in the conscious pregnant ewe and fetus. Am. J. Obstet. Gynecol, 132, 7-15.

BROWN E. H., COGHLAN J. P., HARDY K. J., WINTOUR E. M., 1978. Aldosterone, corticosterone, cortisol, 11-deoxycortisol and 11-deoxycorticosterone concentrations in the blood of chronically cannulated ovine foetuses : effect of ACTH. Acta endocrinol., 88, 364-374.

CARVER J. G., MOTT J. C., 1974. Plasma renin, $\mathrm{Na}^{+}$and $\mathrm{K}^{+}$in immature lambs with indwelling catheters. J. Physiol. (London), 245, 73-75P.

CARVER J. G., MOTT J. C., 1978. Renin substrate in plasma of unanaesthetized pregnant ewes and their foetal lambs. J. Physiol. (London), 276, 395-402.

DRUMMOND W. H., LINDHEIMER C. A., 1982. Plasma renin activity during acute ventilatory hypoxia in the ewe and fetal lambs. Biol. Neonate, 42, 291-298.

DUTTON A., MOTT J. C., 1980. Plasma aldosterone measurements in intact and nephrectomized fetal lambs. J. Physiol. (London), 307, 81-82P.

FLEISCHMAN A. R., OAKES G. K., EPSTEIN M. F., CATT K. J., CHEZ R. A., 1975. Plasma renin activity during ovine pregnancy. Am. J. Physiol, 228, 901-904.

GIRY J., KHALDOUN M., TOURNAIRE C., BARLET J. P., MARTIN-ROSSET W., DELOST P., 1979. L'aldostérone chez la jument en fin de gestation et chez le poulain au cours de la période néonatale. J. Physiol. (Paris), 75, 25A.

IWAMOTO H. S., RUDOLPH A. M., 1981. Role of renin-angiotensin system in response to hemorrhage in fetal sheep. Am. J. Physiol., 240, H848-H854. 
JONES C. T., BODDY K., ROBINSON J. S., 1977. Changes in the concentration of corticotrophin and corticosteroid in the plasma of foetal sheep in the latter half of pregnancy and during labour. J. Endocr., 72, 293-300.

LINGWOOD B., HARDY K. J., COGHLAN J. P., WINTOUR E. M., 1978. Effect of aldosterone on urine composition in the chronically cannulated ovine foetus $J$. Endocr., 76, 553-554.

LUMBERS E. R., LEWES J. L., 1979. The actions of vasoactive drugs on fetal and maternal plasma renin activity. Biol. Neonate, 35, 23-32.

MATTIOLI L., CHIEN S., VASSENON T., CRIST R., LYNN R., 1979. Effect of angiotensin II (A-2) blockade on the response of the fetal lamb to acute hypoxia and hypovolemia. Pediat. Res., 13, 360.

MONCAUP M., GIRY J., BARLET J. P., LEFAIVRE J., DELOST P., 1980. Aldosterone metabolism in pregnant ewes and fetal and newborn lambs. Reprod. Nutr. Dévelop., 20, 277-286.

MOUTQUIN J. M., LIGGINS G. C., 1976. Plasma levels of renin after fetal nephrectomy in sheep. N.Z. Med. J., 84, 114.

MOUTQUIN J. M., LIGGINS G. C., 1981. Effects of partial lower aortic obstruction in the pregnant ewe on fetal arterial pressure, heart rate, plasma renin activity and prostaglandin $E$ concentration. J. Dev. Physiol., 3, 75-84.

OAKES G. K., FLEISCHMAN A. R., CATT K. J., CHEZ R. A., 1977. Plasma renin activity in sheep pregnancy after fetal or maternal nephrectomy. Biol. Neonate, 31, 208-212.

PRADIER P., DALLE M., DAVICCO M. J., LEFAIVRE J., BARLET J.-P., DELOST P., 1985. Plasma $\mathrm{ACTH}$, cortisol and aldosterone concentrations in chronically cannulated ovine fetuses and in lambs injected with ovine corticotropin releasing-factor. J. Dev. Physiol., 7, 259-268.

RICHET E., SAFWATE A., DAVICCO M. J., DALLE M., BARLET J.-P., 1984 Fonction cortisurrénalienne chez le jeune veau, 247-256. In JARRIGE R., Physiologie et pathologie périnatales chez les animaux de la ferme. I.N.R.A., Paris.

ROBILLARD J. E., AYRES N. A., GOMEZ R. A., NAKAMURA K. T., SMITH F. G., 1984 . Factors controlling aldosterone secretion during hypoxemia in fetal lambs. Pediat. Res., 18, 607-611.

ROBILLARD J. E., GOMEZ R. A., MEERNIK J. G., KUEHL W. D., VANORDEN D., 1982a. Role of angiotensin II on the adrenal and vascular responses to hemorrhage during development in fetal lambs. Circ. Res, 50, 645-650.

ROBILLARD J. E., GOMEZ R. A., VANORDEN D., SMITH F. G., 1982b. Comparison of the adrenal and renal responses to angiotensin II in fetal lambs and adult sheep. Circ. Res., $\mathbf{5 0 ,}$ 140-147.

ROBILLARD J. E., RAMBERG E., SESSIONS C., CONSAMUS B., VANORDEN D., WEISMANN D., SMITH F. G., 1980. Role of aldosterone on renal sodium and potassium excretion during fetal life and newborn period. Dev. Pharmacol. Ther., 1, 201-216.

ROUFFET J., DALLE M., DAVICCO M. J., SAFWATE A., 1984. Influence d'un régime hypo ou hypersodé sur l'aldostérone et le cortisol plasmatiques chez la vache et son fœtus en fin de gestation. J. Physiol. (Paris), 79, 84A.

SAFWATE A., 1985. Urinary sodium excretion and the renin-aldosterone system in newborn calves. J. Physiol. (London), 362, 261-271.

SAFWATE A., DAVICCO M. J., BARLET J.-P., DELOST P., 1982a. Sodium and potassium balances and plasma aldosterone levels in newborn calves. Reprod. Nutr. Dévelop., 22, 689-696.

SAFWATE A., DAVICCO M. J., DALLE M., BARLET J.-P., 1984. Electrolyte balance, mode of delivery and plasma aldosterone levels in newborn lambs. Reprod. Nutr. Dévelop., 24, 351360 .

SAFWATE A., RICHET E., BARLET J.-P., DELOST P., 1982b. ACTH and plasma corticosteroid levels in young calves. J. Physiol. (Paris), 78, 195-197.

SIEGEL S. R., 1979. Potassium chloride stimulation of aldosterone in the newborn lamb. J. Pediat., 95, $1051-1054$.

SIEGEL S. R., 1981a. Amniotic fluid concentrations of renin and aldosterone during development in the fetal sheep. Pediat.. Res., 15, 1419-1421.

SIEGEL S. R., 1981b. Decreased vascular and increased adrenal and renal sensitivity to angiotensin II in the newborn lamb. Cir. Res., 48, 34-38. 
SIEGEL S. R., FISHER D., 1977. The renin-angiotensin-aldosterone system in the newborn lamb: response to furosemide. Pediat. Res., 11, 837-839.

SIEGEL S. R., FISHER D., 1979. The effects of angiotensin II blockade and nephrectomy on the renin-angiotensin-aldosterone system in the newborn lamb. Pediat. Res., 13, 603-605.

SIEGEL S. R., FISHER D., 1980. Ontogeny of the renin-angiotensin-aldosterone system in the fetal and newborn lamb. Pediat. Res, 14, 99-102.

SIEGEL S. R., OAKES G., PALMER S., 1981a. Transplacental transfer of aldosterone and its effects on renal function in the fetal lamb. Pediat. Res., 15, 163-165.

SIEGEL S. R., OAKES G., PALMER S., 1981b. Effects of angiotensin II on blood pressure, plasma renin activity and aldosterone in the fetal lamb. Dev. Pharmacol. Ther., 3, 144-149.

SMITH F. G., LUPU A. N., BARAJAS L., BAUER R., BASHORE R. A., 1974. The reninangiotensin system in the fetal lamb. Pediat. Res., 8, 611-620.

TRIMPER C. E., LUMBERS E. R., 1972. The renin-angiotensin system in fetal lambs Pflügers Arch., 336, 1-10.

WEISMANN D. N., HERRIG J. E., McWEENY O. J., ROBILLARD J. E., 1983. Organ tissue blood flow responses to hypoxemia in lambs : effect of angiotensin convertingenzyme inhibitor. Pediat. Res., 17, 195-199.

WILSON T. A., KAISER D. L., WRIGHT E. M., ORTT E. M., FREEDLENDER A. E., PEACH M. J., CAREY R. M., 1981. Importance of plasma angiotensin concentrations in a comparative study of responses to angiotensin in the maturing newborn lamb. Hypertension, 3. II-18-II-24.

WINTOUR E. M., BROWN E. H., DENTON D. A., HARDY K. J., MCDOUGALL J. G., ODDIE C. J., WHIPP G. T., 1975. The ontogeny and regulation of corticosteroid secretion by the ovine foetal adrenal. Acta endocrinol., 79, 301-316.

WINTOUR E. M., COGHLAN J. P., HARDY K. J., LINGWOOD B. E., RAYNER M., SCOGGINS B. A., 1980. Placental transfer of aldosterone in the sheep. J. Endocr., 86,305310.

WINTOUR E. M., MARELYN E., BARNES A., CAHILL F., HARDY K. J., HORACEK I., SCOGGINS B. A., 1979. Potassium : aldosterone relationships in pregnant ewes and chronically cannulated ovine fetuses. Pediat. Res., 13, 265-267. 